\title{
NEW MAUNA LOA OBSERVATORY UNIT
}

\author{
By ROY L. FOX \\ Meteorologist in Charge, Pacific Area, U.S. Weather Bureau
}

\begin{abstract}
A NEW high-altitude unit of the Mauna Loa Observatory to be used for observations and research projects was recently completed and dedicated. 'This unit, termed the 'slope' unit of the Observatory, is situated on the north slope of Mauna Loa at an elevation of 11,134 ft. above sea-level and is accessible over a gradual grade highway constructed of crushed lava and volcanic cinders. It is a companion unit to the much smaller and decidedly less accessible unit of the Observatory erected in 1951 at an elevation of $13,453 \mathrm{ft}$. near the summit of the mountain.
\end{abstract}

Its setting is the large volcanic mountain, Mauna $\mathrm{I}_{\mathrm{t}} \mathrm{a}$, often referred to as one of the largest single land masses in the world. 'The mountain comprises approximately half the island of Hawaii, the largest and south-easternmost of the Hawaiian Islands, and is noted not only for its massiveness but also for its very gradual slopes with almost constant grade. 'The "straight line' average grade ovər a distance of approximately forty miles along the north-east slope from the summit, at $13,680 \mathrm{ft}$. above sea-level, to the sea in the vicinity of Irilo, the principal city on the Island, is less than 7 per cent. 'I'his is the slope traversed by the highway to the Observatory and also the one almost directly facing the prevailing quarter from which the trade winds in the vicinity of the Hawaiian Islands blow.

A trip up this highway to the 'slope' unit from Hilo carries one from a point near sea-level, where the average annual rainfall is $140 \mathrm{in}$., past the region of maximum rainfall near $3,000 \mathrm{ft}$. above sea-level, where it is more than $240 \mathrm{in}$., thence through a section of rapidly decreasing rainfall with height and then to the area from around 9,000 ft. to the Observatory unit, where the average annual rainfall is just under 20 in. The vegetation zones along the roadway serve as excellent climatic indicators and strikingly attest to these rainfall regimes. For the first $1,500 \mathrm{ft}$. or so of elevation the vegetation is predominantly shrub and closed forest. A dense tropical rain forest extends from around 1,500 ft. to near 5,500 ft. above sea-level, where vegetation begins to thin. Open forest then prevails for sorne distance, giving way to upland open shrub-type vegetation which, in turn, is replaced by a sparse growth of the primitive plant forms such as fungi, lichens and some mosses existing in the lava wastelands.

The 'slope' unit is housed in a pleasant one-story concrete block building, $20 \mathrm{ft} . \times 40 \mathrm{ft}$., partitioned. into a $16 \mathrm{ft}$. $\times 20 \mathrm{ft}$. combination laboratory and work. shop, three bedrooms and a combined kitchenette and dining room. There is also a ground-level concrete pad $15 \mathrm{ft}$. $\times 45 \mathrm{ft}$. for basing instruments, a raised wooden instrument platform and two instrument and antenna towers. It develops it own electrical power from its diesel-operated generating system. It also has its own radio communications link with the Weather Bureau Office in Hilo, an electrical lighting system and a water catchment and water storage and distribution units as well as a space heater, water heater, cooking range and refrigerator, all using butane.

The Mauna Loa Observatory is operated by the U.S. Weather Bureau, but at present it is not staffed on a fully continuous basis. Plans are, however, to have personnel regularly man the station and attend the instruments on four days of each week beginning in the very near future. For the remaining portion of each week, meteorological data will then usually be obtained, as they are now, by recording devices alone. However, for those periods when special research projects are being carried on at the Observatory by other groups through arrangements with the Weather Bureau, the meteorological instruments, along with other types of equipment, will be attended daily, and data on recorder records will be supplementer with visual data. Ultimately, if plans mater. ialize, the Observatory will be staffed continuously, year in and year out.

The usual meteorological instruments, most with recording features, are now in use or soon will be in use at the Observatory. Data to be obtained on a continuous basis are wind speed and direction, pres. sure, temperature, humidity and rainfall. Additional data being anticipated for interrupted periods of several days per week are duration of sunshine, sky cover, cloud types and amounts, current weather and related features and pilot-balloon information. It is also expected that, when the Observatory is operated on a continuous basis, all these elements will be observed and/or recorded continuously, day in and day out, and that there will also be such additional measurements as those of solar radiation and ozone content of the air and that possibly some highvolume dust sampling and other dust measurements will be made.

Its accessibility, fine living accommodation and excellent provisions for hasing instruments make this 'slope' unit particularly useful for special short-period projects. Other attractive features are its tropical location, its altitude-which is well above the usual height of the trade wind inversion in this tropical mid-Pacific area and which places it above much of the atmosphere's moisture and trade wind cumulus cloudiness most of the time-and its great distance from any large continental land masses and industrial areas.

The Observatory's high-altitude setting at a tropical location near the centre of the largest ocean on the globe makes it a unique facility. It is also less than a seven-hour trip from Honolulu, the travel hub of the Pacific, from which the first portion of the trip is by air to Hilo, thence up the mountain highway by motor-car.

One special project, namely, a series of spectrographic observations of the atmosphere of the planet. Mars by a group of National Geographic Society scientists, has recently been completed at the Observatory. During the coming winter, it is hoped to study the structure of naturally formed snow crystals in an atmosphere with limited quantities of aerosols. Also arranged for next spring is a special study of solar radiation.

Preliminary negotiations for use of the 'slope' unit for a special project should be with the Chief of the Weather Bureau, by writing to the Chief of tho Observations and Stations Facilities Division, U.S. Weather Bureau, Washington 25, D.C. 